\title{
Advocacy for Multiculturalism and Immigrants' Rights: The Effect of U. S. Immigration Legislation on American Public Libraries, 1876-2020
}

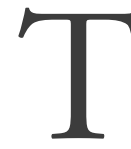
he American Library Association (ALA), founded in 1876, demonstrated its advocacy for immigrants' rights and multiculturalism in adult library services from 1918 to 1948 through the Committee on Work with the Foreign Born (CWFB), which served as a clearinghouse for Americanization (assimilation) services within a philosophical framework of cultural pluralism, now known as multiculturalism. The ALA CWFB throughout its existence depended on grants from the Carnegie Corporation from 1911 to 1961 through the American Association for Adult Education (1915-41), and the Ford Foundation, through its Fund for Adult Education (1951-61). Beginning in 1956 with the Library Services Act, the federal government began to fund libraries, including programs for immigrants, African Americans, Native Americans, and illiterate adults. Since 1972, the Reference \& User Services Association (RUSA) has provided literacy training for foreign- and native-born adult illiterates; and the Public Library Association (PLA) has supported programs to prepare New Americans for citizenship. Since 1983, the ALA Ethnic and Multicultural Information Exchange Round Table (EMIERT) has encouraged access to multicultural publications and collaborates with ALA affiliates for various ethnic and minority groups. The ALA advocates for the rights of DACA recipients and supports the need for a DREAMER (Development, Relief, and Education for Alien Minors) Act. Library advocacy for immigrants is increasingly dependent on the U.S. Congress to reform a broken and unfair immigration system.

\section{Prologue \& Socio-Political Context}

The history of immigration to the United States is inextricably tied to slavery, the naturalization process, citizenship, including the right to vote, and the treatment of American Indians. Beginning in 1607 with the first permanent English colony in the New World, Jamestowne, immigration has continued for over four centuries, but progress in these areas of concern has been painfully slow, piecemeal, and debated open-endedly without solving the problems or simply ignored.

From the very beginning the immigration system of the United States has been based on racist and sexist thinking. The first enslaved Africans were brought to Point Comfort, Virginia, near Jamestowne, in 1619. Shortly after the establishment of the United States of America, the U.S. Congress passed the 1790 Act, which limited citizenship to white men only. The descendants of the African immigrants to Jamestowne and thousands more brought to the United States thereafter were neither white nor free and thus ineligible for naturalization and citizenship.

The American Civil War from 1861-65 was fought primarily to eliminate slavery and thus preserve the union. Three years later, in 1868, the Fourteenth Amendment to the U.S. Constitution declared former slaves free and citizens of the United States. After the war, Reconstruction in the South coupled with Jim Crow racial laws blocked the progress of African Americans for a century more until they won the right to vote in 1965 .

Not to be forgotten, the Native American Indians met by English colonists in 1607 Jamestowne and their descendants would not be recognized as citizens until 1924. American Indian veterans of World War I were granted citizenship for their service five years earlier, in 1919, just one year before women won the right to vote in $1920 .{ }^{1}$

These historical facts must be taken into consideration when viewing the role of American public libraries in a country with a divided population regarding immigration and immigrants. Conservatives or nativists, have supported the limitation, if not elimination of immigration. Liberals or progressives have sought ways to serve immigrants and minorities and to

\footnotetext{
1. Lovia Gvarkye, "How the 1619 Project Came Together, New York Times, 18 Aug. 2019, p. A2(L),http://link.gale.com/apps/doc/A596676229/SCIC?u=ncl iveecu\&sid=SCIC\&xid=7b3a2855; Michael LeMay and Elliott Robert Barkan, eds., U.S. Immigration and Naturalization Laws and Issues: A Documentary History (Westport, CT: Greenwood Press, 1999, 49-56, 72-76 88-89; Maldwyn Allen Jones, American Immigration, 2nd ed. (Chicago, IL: University of Chicago Press, 1992), 175, 213-14, 226, 231; Rudolf J. Vecoli, "Immigration," in Oxford Companion to United States History, ed. Paul S. Boyer and Melvyn Dubofsky (New York, NY: Oxford University Press, 361-62; William S. Bernard, "Immigration: History of U.S. Policy," in Harvard Encyclopedia of American Ethnic Groups, ed. Stephan Thernstrom, Ann Orlov, and Oscar Handlin (Cambridge, MA: Belknap Press of Harvard University Press, 1980). 490, Reed Ueda, "Naturalization and Citizenship," 740; and Harlow G. Unger, ed., "American Indian," in Encyclopedia of American Education, 2nd ed. (New York, NY: Facts on File, c2001, 1996), 64-67.
} 
promote multiculturalism. Public librarians have worked within the framework of immigration legislation passed by the U.S. Congress and have been subject to the changing policies of the federal government as the debate on immigration reform ebbed and flowed.

\section{Founding of the American Library Association (ALA)}

The American Library Association (ALA) was founded in 1876 as part of the Centennial celebration of the founding of the United States of America and represented the first national coordination of American public library service. Progressive Era reformers called for public libraries to address the needs of not only white citizens but increasingly the needs of the newly enfranchised African Americans in addition to the needs of a continuing with the 1882 Chinese Exclusion Act, and some twenty-five years later, in 1907-8, the Gentlemen's Agreement to curtail immigration from Japan. ${ }^{3}$

\section{Americanization Programs and Public Library Commissions}

Prior to World War I, in the absence of any national coordination of the Americanization campaign, governmental and quasi-governmental agencies competed to provide Americanization programs for the flood of immigrants fleeing political, social, and economic upheavals in their European homelands for the hoped-for promise of improving their economic status and protecting themselves from persecution. These agencies included, in the former category, the U.S. Bureau of Naturalization, administered by the
Philadelphia, Cleveland, and Chicago. Immigrants discovered that public libraries were free to use and provided books in their native languages as well as instruction in English and preparation for naturalization that would lead to full citizenship in their new country.

In response to the Progressive Era's reforming spirit, Americanization services were also provided beginning in 1890 by state public library commissions, beginning with the Massachusetts Free Public Library Commission (MFPLC), the first state library commission established as well as the first to offer Americanization services to immigrants on a statewide basis beginning in 1913. Jane Maud Campbell was employed by the MFPLC to supervise library work with immigrants statewide, the first woman to hold such a position. Other state public library

\section{6 ... historical facts must be taken into consideration when viewing the role of American public libraries in a country with a divided population regarding immigration and immigrants.}

influx of immigrants, mostly from Europe, that had begun in the early 1800s. The public libraries of several large cities and states with large immigrant populations, particularly in the Northeast and Midwest, were already in the business of supplying books in languages other than English and helping immigrants to assimilate in their new homeland. ${ }^{2}$

The movement toward restricting or at least limiting the migration of immigrants from the Far East gained Congressional approval prior to World War I. The U.S. Congress passed legislation to bar immigration from China
Department of Labor; and the Division of Immigrant Education of the U.S. Bureau of Education, administered by the Department of Interior; and, in the latter category, the Committee on Information, which later was incorporated as the independent Foreign Language Information Service (FLIS). ${ }^{4}$

Public librarians, often branch librarians in large Northeastern and Midwestern cities, were enthusiastic or at least willing to serve the newly arrived immigrants, who found their way to their branch libraries in the heart of neighborhoods in major urban centers like New York, Boston, commissions soon followed the example of the MFPLC. By 1904, the League of Library Commissions was established to open communication among state public library commissions across the country. ${ }^{5}$

\section{ALA War Service}

During World War I and its aftermath ALA formally began to provide national coordination for Americanization services in public libraries. The ALA's national success, earned by providing books to foreign and nativeborn soldiers and sailors during World War I, encouraged ALA leaders to

2. Charles A. Seavey, "Public Libraries," in Encyclopedia of Library History, ed. Wayne Wiegand and Donald G. Davis, Jr. (New York, NY: Garland Publishing, 1994), 521, 518-28; Frank B. Sessa, "Public Libraries, International: History of the Public Library," in Encyclopedia of Library and Information Science, ed. Allen Kent, Harold Lancour, and Jay E. Daily, vol. 24 (New York, NY: Marcel Dekker, 1976), 285.

3. Otis L. Graham, Jr., Unguarded Gates: A History of America's Immigration Crisis (Lanham, MD: Rowman \& Littlefield Publishers, 2004 ), 6, 9, 15 , 17.

4. John F. McClymer, "Americanization Movement," in Dictionary of American Immigration History, 23-28.

5. Charles F. D. Belden, "Library Commission Work in Massachusetts,": Library Journal 42 (Jan. 1917); 5-10; Massachusetts Free Public Library Commission Annual Report 1912/13, 16; Minnie Clarke Budlong, "League of Library Commissions," Bulletin of the American Library Association 8, (1) (1914): $20-25$. 
consider ways to continue this success in peacetime. The ALA received a grant of $\$ 320,000$ from the Carnegie Corporation of New York for the ALA War Service Committee, led by Herbert Putnam and Carl H. Milam. ${ }^{6}$

\section{ALA Committee on Work with Foreign Born, 1918-1948}

The ALA Committee on Work with the Foreign Born (CWFB), established in February 1918, was the first ALA organization charged exclusively to serve immigrants as a clearly defined population. Established to support and continue the work that had already been accomplished with the foreignborn community before and after World War I, the ALA CWFB's mission was straightforward: "to collect from libraries and to supply to them information on desirable methods of assisting in the education of the foreign born, in American ideals and customs and the English language."7 This was the explicit mission. The implicit mission adhered to by many librarians and immigrants' rights advocates was to provide Americanization services without force and coercion, without the mandate for immediate conformity, and within a framework of advocacy for "cultural pluralism," a new sociological construct made popular by Horace Kallen and embraced by other Progressive Era reformers. ${ }^{8}$
The ALA Executive Board appointed as the ALA CWFB's first chair, John Foster Carr, then an ALA employee as well as Founder and Director and sole employee of his Immigrant Publication Society of New York. Carr had been a particularly active and effective in the massive ALA book drive for soldiers and sailors during World War I. During the decade prior to his appointment, Carr had gained national attention for the publication of his series of Guides to the United States for various immigrant groups, including, in addition to an English edition, versions for Italian, Jewish, and Polish immigrants. ${ }^{9}$

\section{ALA Enlarged Program}

The ALA Executive Board sought to retain the hard-won national recognition for its ALA War Service during World War I by following up with a proposed ALA Enlarged Program, a national program of services to meet the needs of populations already identified and experimented with by the social reformers of the Progressive Era. Carr, concurrently the first chair of the ALA CWFB, was responsible for the financial management of this new campaign to expand library services not only to immigrants but also to other unserved or underserved populations.

Two million dollars were needed for implementing library extension or outreach services, work with the foreign born, adult self-education, work with the blind, and institutional library development. Rather than being approved by many ALA members, however, the ALA Enlarged Program threatened to tear apart the organization. Vocal librarians objected that while they supported the public library's role in scholarship, many complained that they had not accepted that the ALA had a role to play in adult self-education, a new untested concept. Many librarians questioned the ALA's provision of services directly to readers, implying that this smacked of welfare rather than professionalism. Proposed changes to the ALA constitution to develop centralized administration for the Enlarged Program and the proposed move of ALA headquarters from Chicago to New York were challenged and financial mismanagement was charged. In sum, the library community was not ready to engage in yet another fund-raising campaign without the slightest hope of matching the success of the ALA War Service.

The ALA Enlarged Program, for these and a multitude of other reasons, became hopelessly deadlocked. The ALA Executive Board, chaired by Carl H. Milam, was forced to close the fund-raising campaign in December 1920 , and, according to Margaret Monroe, writing in the 1960s about the ALA library adult education (formerly known as adult self-education) program and the ALA Enlarged Program, "a curtain of silence was

6. Dennis Thomison, A History of the American Library Association, 1876-1972 (Chicago, IL: ALA, 1980, copr. 1978), 70-71.

7. American Library Association (ALA), 1918, Library Journal 43 (2): 120 (quote).

8. Wayne A. Wiegand, "Educating the Immigrant: The Americanization Movement and the Public Library, 1917-18, 113-31, in "An Active Instrument for Propaganda": The American Public Library During World War I, foreword by Edward G. Holley, Beta Phi Mu Monograph, Number 1 (Westport, CT: Greenwood Press, 1989), 115; Margaret E. Monroe, Library Adult Education: The Biography of an Idea (New York, NY: Scarecrow Press, 1963), 25-27; Horace M. Kallen, "Democracy versus The Melting-Pot," Nation 100 (!8. Feb. 1915: 190-94), and (25 Feb. 1915): 217-20; Horace M. Kallen, Culture and Democracy in the United States: Studies in the Group Psychology of the American Peoples (New York, Y: Boni and Liveright, 1924; reprint, New York, NY: Arno Press and the New York Times, 1970).

9. John Foster Carr, Guide to the United States for the Immigrant Italian: A Nearly Literal Translation of the Italian Version, published under the auspices of the Connecticut Daughters of the American Revolution (Garden City, NY: Doubleday, Page, 1911); Plummer Alston Jones, Jr., "The ALA Committee on Work with the Foreign Born and the Movement to Americanize the Immigrant," in Libraries to the People: Histories of Outreach, 100-102, ed. by Robert S. Freeman and David M. Hovde, with a foreword by Kathleen de la Pena McCook (Jefferson, NC: McFarland, 2003). 
drawn over both the program and the debates," as if it had never happened. ${ }^{10}$

Carr, who had in the meantime served as chair of the ALA CWFB for two terms, was relieved of his position with the ALA after December 1920, his reputation tainted by his association with the widely criticized ALA Enlarged Program and his failure to raise anywhere near the two-million-dollar goal. Carr was however the catalyst to get ALA to reexamine its mission "to provide the best reading for the most at the least cost" (the words of Melvil Dewey), including those who, at this critical point in their lives, dreamed of becoming citizens of their new homeland and sought help from any organization that would help them. Fortunately for the library work with the foreign born movement, Carr was replaced in the 1920-21 term by Eleanor (Edwards) Ledbetter of Cleveland, who served for six consecutive terms as chair of the ALA CWFB, during the formative years from 1920-21 to $1925-26$.

Ledbetter shared Carr's passion for library work with immigrants, but as a cultural pluralist, not an Angloconformist. The promotion of and advocacy for multiculturalism in library services became driving forces increasingly during Ledbetter's administration of the ALA CWFB. Her leadership brought stability to the ALA CWFB, which continued its program of service to immigrants even as the U.S. Congress was debating and putting the final touches on an elaborate quota system based on national origins of future immigrants. The purpose of the quotas was a ruse to allow more immigration from

countries in Western Europe at the expense of decreasing the flow of new immigrants from Eastern Europe. ${ }^{11}$

\section{National Origins Act (1924)}

In 1921, Congress passed the first of two blatantly racist quota acts, which established the quota principle based on three percent of the foreign-born population in the 1910 census. It was within three years replaced by the Immigration Act of 1924, known as the National Origins Act, which was passed by the Congress to establish national origin quotas based on two percent of the census of the 1890 foreign-born population. The national origins quota system shifted the flow of Eastern Hemisphere immigration from Southern, Central, and Eastern Europe to immigration from Northwestern Europe. The act barred the admission of most Asians, who had already been legally classified as ineligible for citizenship. $^{12}$

\section{Although viewed as a victory for anti-} immigration forces within the Congress and the country at large, the implementation of the National
Origins Act had unforeseen consequences.

Although viewed as a victory for anti-immigration forces within the Congress and the country at large, the implementation of the National Origins Act had unforeseen consequences. First, immigrant customs and traditions transferred to the New World were becoming harder to maintain without the constant infusion of more immigrants from Europe: immigrants were being Americanized more quickly than before. Second, the new law allowed for the concentration of Americanization efforts on second and third generations of the immigrant community rather than on newcomers only. As a result of these two influences, the ALA CWFB began to rely more and more on the public schools for the Americanization of children, and on local boards of education and industries for the provision of adult evening schools.

The failure of the ALA Enlarged Program brought about a conservative wait-and-see policy to an already conservative ALA during the early 1920s and, as a counterbalance, the beginning of a reexamination of what had gone wrong. ALA leaders found it difficult to abandon their typical conservative attitudes and purported that to do anything would jeopardize their expressed neutrality on social issues. However, there were in ALA's existing programs a variety of library services for adults already being delivered by public libraries that promised to be popular, helpful, and non-confrontational. These core services included reading guidance (known as readers' advisory service); services for special groups, notably immigrants, but also youth and adults with little education; departmentalization of libraries based on subject; and services in collaboration with community organizations

10. P. A. Jones, Jr., 1999, “The Publisher as Propagandist: John Foster Carr, 1869-1939,” in Libraries, Immigrants, and the American Experience (Westport, CT: Greenwood Press, 1999) 81-86.

11. P. A. Jones, Jr., "The Librarian as Social Worker; Eleanor (Edwards) Ledbetter, 1870-1954," in Libraries, Immigrants, and the American Experience, 141. 12. LeMay and Barkan, U.S. Immigration and Naturalization Laws and issues, 136-40; 144-51; Sucheng Chan, "Japanese," in Dictionary of American Immigration History, 439, Raymond B. Williams, "Asian Indians," 45, Ueda, "Naturalization and Citizenship,” 741; P.A. Jones, Jr., "The ALA Committee on Work with the Foreign Born and the Movement to Americanize the Immigrant," 96-110. 
and agencies. In the aftermath of World War II, library sponsorship of educational programs to promote democratic values in an increasingly pluralistic society assumed more urgency. ${ }^{13}$

\section{ALA Adult Education Programs and Carnegie Corporation of New York}

Under the organizational leadership of the ALA Adult Education Board, from its beginnings in 1924 as the ALA Commission on the Library and Education, the new library adult education movement received extensive funding and guidance from educational foundations. Millions of dollars in grants came to the ALA from the Carnegie Corporation of New York. The Carnegie Corporation's support of libraries was typical of its total adult education program, including the subsidizing of surveys, publications, research, demonstration projects, and experimental programs, as well as promoting professional participation in local, state, and national adult education associations. The Carnegie Corporation from its beginning was influenced by conservative leaders, including its early presidents. Under the leadership of Frederick Keppel, the Carnegie Corporation officially recognized the public library as a major agency for promoting adult education. $^{14}$

In 1924, William Learned, an associate of the Carnegie Corporation, agreed with Keppel about the potential of the public library as an agency for adult education in his The American Public Library and the Diffusion of Knowledge. Endorsed by president Keppel for distribution to a wider audience, the Learned report included a summary of significant adult library services already developed and implemented in public libraries, including subject departments in the Cleveland Public Library; reading courses available for purchase in the Chicago Public Library; the ALA Reading Courses series; and the U.S. Bureau of Education reading courses series. According to Learned himself, the report represented a philosophical framework, not only for adult education per se, but also for the diffusion of ideas and general knowledge, a concept framed in the Corporation's mission. The Carnegie Corporation considered services to immigrants an integral part of library adult education, and through its funding of the ALA itself, the Corporation indirectly continued the funding for the ALA CWFB. ${ }^{15}$ An ulterior motive for the Corporation leadership's concern for immigrants was that if the needs of immigrants were placated, the potential for social unrest was decreased.

Although the Learned report did not mention specifically the work of the ALA CWFB, it was at least possible that Learned knew about a series of publications by ALA CWFB members in the Library Journal during the early 1920s that demonstrated the CWFB's commitment to readers' advisory and guidance programs.
Individual articles in the series focused on the reading habits of different immigrant and ethnic groups, including Yiddish-speaking Jews (1921), Poles (1922), Japanese (1922), Romanians (1922), Greeks, Czechoslovaks (1923), and Italians (1924). ${ }^{16}$ These immigrant groups were representative of the new immigrants with the unexpected exception of the Japanese, who at this point in U.S. immigration policy were not officially welcomed in the Gentlemen's Agreement with Japan of 1907-8.

In January 1924, the ALA Bulletin's editorial column announced a general membership session on the topic of library adult education at the upcoming ALA annual conference that summer in Saratoga Springs, New York. Judson T. Jennings, librarian of the Seattle Public Library, and then ALA President, would address the ALA membership. In line with recommendations in the Learned report, Jennings endorsed public librarianship's interest in adult education, and identified three short-term objectives for the ALA: training competent personnel; extending library service to all areas of the country, notably rural areas; and participating in the developing national adult education movement. Jennings recommended that every large public library employ readers' advisers for reading guidance; develop reading courses, particularly for what was called out-of-school youth; and encourage the publishing of readable interesting books to be provided in

13. Monroe, 27-28, 31-32; John Michael Handley, “The Carnegie Corporation and the American Association for Adult Education," EdD dissertation (Raleigh, NC: North Carolina State University, 1998).

14. Florence Anderson, Carnegie Corporation: Library Program, 1911-1961 (New York, NY: Carnegie Corporation, 1963), 88-89.

15. William Learned, 1924, The American Public Library and the Diffusion of Knowledge (New York, NY: Harcourt, Brace), iii, 3, 7, 28-29, 31, 33-36, 38-40, 56; Monroe, 1963, 228-230.

16. David Pinski, and Jennie Meyrowitz, 1921, "Yiddish Literature," Library Journal 46 (21): 977-79; Eleanor (Edwards) Ledbetter, 1922, "The Polish Immigrant and the Library [Part I]," Library Journal 47 (2): 67-70; "The Polish Immigrant and the Library [Part II]," Library Journal 47 (11): $496-98$; Ledbetter, 1923, “The Czechoslovak Immigrant and the Library," Library Journal 48 (19): 911-15; Marion Horton, "Library Work with the Japanese," Library Journal 47 (15 Feb. 1922); Josephine Gratiaa, 1922, "Roumanians [sic] in the United States and Their Relations to Public Libraries," Library Journal 47 (9): 400-404; Margery Quigley, 1922, “The Greek Immigrant and the Library," Library Journal 47 (18): 863-65; May M. Sweet, "Italians and the Public Library," Library Journal 49 (15 Nov. 1924): 977-81. 
quantities at low cost, an allusion both to Melvil Dewey's motto for the ALA approved in 1879, and to the Carnegie Corporation's mission of diffusing knowledge and ideas to the greatest number. ${ }^{17}$

Reaction to Jennings's speech was generally enthusiastic, especially when compared to the total rejection of ALA Enlarged Program. Jennings was appointed chairman of the ALA Commission of the Library and Adult Education in 1924 and instructed to conduct a two-year study of libraries and their potential for promoting adult education. In 1925, the Carnegie Corporation granted the ALA $\$ 24,500$ for this study and formed an advisory committee, which included John Cotton Dana of the Newark Public Library, known for his sharp criticism of the very concept of adult education, along with Carl H. Milam, ALA Executive Director, as official representatives of the ALA. Together, representatives from the library and adult education communities would take steps in the formation of what would become, in 1926, the American Association for Adult Education (AAAE), which would work in tandem as a subsidiary organization with the Carnegie Corporation to promote and advocate the growing interest in adult education through public libraries. ${ }^{18}$

In 1926, the ALA Commission's report, Libraries and Adult Education, recommended, not surprisingly, that public libraries should organize adult education departments and programs adapted to the needs of what were termed special groups, including immigrants, workers, unions, university extension students, public school youth, the blind, and inmates of hospitals and prisons. Librarians began to look especially to the readers' advisers and specialist librarians, who had adapted traditional services to the needs of special groups in the community, as the appropriate leaders for library adult education.

Also, in March 1926, the ALA Commission became the ALA Board on the Library and Adult Education. With the consensus of library community opinion being that the readers' advisory service was the principal focus of adult education, the American public library community had a clearer vision of its role as an agency of library adult education. Critics like Dana warned of the overreliance on the readers' adviser's role considering the library's role of neutrality in a pluralistic democratic society. ${ }^{19}$

From 1926 through 1933, the Carnegie Corporation granted the ALA two million dollars for its endowment. In 1929, the ALA CWFB, under the leadership of Edna Phillips of the MFPLC Division of Public Libraries, Jane Maud Campbell's successor as Supervisor for Work with Racial Groups, published a handbook entitled Reading Service to the Foreign Born, which offered suggestions on how to introduce the public library's Americanization services to adult immigrants in evening school classes. ${ }^{20}$ This and other publications of the ALA CWFB's demonstrated a willingness to provide what the Carnegie Corporation's and the ALA's leadership had recommended.

\section{American Association for Adult Education}

In 1934, the first edition of the Handbook of Adult Education was published by the AAAE, followed in 1936 by a second edition. The Handbook in these and later editions included articles on, and directories of organizations involved in adult education. An article in the 1934 edition, entitled "Library Adult Education,” by Carl H. Milam, ALA Executive Secretary, outlined the types of services available to the foreign born and positioned the ALA as a supporter of the larger national adult education movement. ${ }^{21}$

Another article that appeared in both the 1934 and 1936 editions of the Handbook, "Adult Education and the Foreign Born," by Read Lewis, Director of the Foreign Language Information Service (FLIS), brought national attention specifically to the ALA CWFB's work with immigrant education:

Although immigration has played no small part in the adult education movement, it has always been something of a stepchild. However convenient, the term "adult education for the foreign born" is apt to be misleading. Instruction in our language and institutions is only a small section of the educational needs and interests of the foreign born. Once the hurdle of language is overcome, adult education is

17. Judson T. Jennings, 1924, "Sticking to Our Last," ALA Bulletin 18 (Proceedings): 150-56; John Cotton Dana, 1928, "To the Members of the Executive Board of the ALA," ALA Bulletin 22 (1): 9-12; Monroe, 1963, 30-32, 34-38.

18. ALA, Commission on the Library and Adult Education, 1926, Libraries and Adult Education (Chicago, IL: ALA); Monroe, 1963, 32-34; Chronology of Milestones for Libraries and Adult Lifelong Learning and Literacy, 2002, Prepared for the ALA Committee on Literacy, by Kathleen de la Pena McCook and Peggy Barber (Washington, DC: ERIC) 2; Wiegand, Irrepressible Reformer: A Biography of Melvil Dewey (Chicago, IL: ALA, 1996), 61-62.

19. Anderson, 88; John Cotton Dana, “To the Members of the Executive Board of the ALA,” ALA Bulletin 22 (1) (1928): 9-12' Monroe, 30-32, 34 -38.

20. Reading Service to the Foreign Born, 1929, comp. by the Committee on Work with the Foreign Born of the American Library Association (Chicago, IL: ALA).

21. Carl H. Milam, 1934, "Libraries and Adult Education," in Handbook of Adult Education in the United States, 1934, ed. by Dorothy Rowden (New York, NY: AAAE). 
essentially the same, whether the student was born in Poland or Pennsylvania. ${ }^{22}$

This observation from someone in an independent organization, which collaborated with public libraries to provide accurate and up-to-date information on immigrant groups, emphasized that, while library work with the foreign born remained essential, it was often overlooked in the preoccupation of the library profession with the administration of library adult education per se, rather than with its content and intended audiences.

In the 1936 edition of the Handbook, Milam's article is replaced by one by John Chancellor, the newly appointed ALA Assistant in Adult Education, titled "Libraries and Adult Education." Chancellor did not mention or discuss library services with the foreign born. Following his article, however, were responses from public libraries throughout the country which had responded to Chancellor's request for summaries of their adult library services, including assimilation services offered. ${ }^{23}$

\section{ALA Adult Education Board and Library Bill of Rights}

Between 1936 and 1940, libraries began to move responsibility for adult education away from being a specialized service of the reader's adviser and toward diffusing the responsibility for library adult education to all professional staff serving adults, both foreign- and native-born. In 1939, Ernestine Rose, then chair of the ALA Adult Education Board, shepherded the first Library Bill of Rights through the ALA Council. Three principles or rights affecting the provision of service to the foreign-born community were identified in the Library Bill of Rights. First, reading materials should be selected in terms of their value and interest to the public, and not influenced by race, nationality, or political views. Second, giving adequate representation of all sides of questions on which differences of opinion existed was an important step to reinforce the library's policy of neutrality in a democratic society. Third, making library meeting facilities available for cultural activities, including the discussion of current national issues, would further demonstrate the library's role as a sponsor of community activities and a forum for the discussion of ideas. The ALA Bill of Rights gave a philosophical underpinning to the adult education activities of the ALA and further enhanced the work of the ALA CWFB. ${ }^{24}$

\section{ALA Adult Services during World War II}

The beginning of World War II affected not only the overall ALA adult education program, but also the activities of the ALA CWFB. A critical shortage of labor occurred in the United States during World War II, due to the redirection of American manpower away from domestic industrial and agricultural enterprises and toward support for the war effort. At the same time, European immigration decreased.

The plight of European refugees from Nazi Germany in general and specifically refugee librarians, was addressed by the ALA Committee on Refugee Librarians, chaired by Jennie M. Flexner, in charge of readers' advisory services at the New York Public Library, and concurrently chair of the ALA CWFB. From 1941 to 1942 the ALA Committee on Refugee Librarians received a grant of $\$ 200$ from the Carnegie Corporation. ${ }^{25}$

These developments had an alarming effect on the ALA CWFB. Mary B. McLellan, librarian responsible for Americanization services at the Hartford Public Library, voiced her reaction to the current situation in her article, "There's Still Work to Be Done with the Foreign Born." McLellan reported that even though the numbers of immigrants entering the country had been decreased by restrictive legislation, there were still, according to the 1940 census, more than 11,500,000 foreign born of whom approximately $3,500,000$ had not been naturalized. ${ }^{26}$

Since immigration from areas throughout the Western Hemisphere was unaffected by the National Origins Act of 1924, the importation of migrant laborers from Mexico was the most viable solution to meet the need for agricultural workers to harvest crops during wartime. To aid

22. Read Lewis, 1934, "Adult Education and the Foreign Born," in Handbook of Adult Education in the United States, 1934, 58-61, 61 (quote), comp. under the auspices of the American Association for Adult Education, Dorothy Rowden, ed. (New York, NY: American Association for Adult Education); Lewis, 1936, "Adult Education and the Foreign Born," in Handbook of Adult Education in the United States, 1936, 58-61, 61 (quote), comp. under the auspices of the American Association for Adult Education, Dorothy Rowden, ed. (New York, NY: American Association for Adult Education). See also, This America: A Summary of the Work of the Foreign Language Information Service, 1927 (New York: Foreign Language Information Service); and Daniel Erwin Weinberg, 1973, "The Foreign Language Information Service and the Foreign Born, 1918-1939: A Case Study of Cultural Assimilation Viewed as a Problem in Social Technology" (Ph.D. dissertation, University of Minnesota).

23. John Chancellor, 1936, "Libraries and Adult Education," in Handbook of Adult Education in the United States, 1936, 77-83, comp. under the auspices of the American Association for Adult Education, Dorothy Rowden, ed. (New York, NY: American Association for Adult Education).

24. ALA, 1948c, "Library Bill of Rights," ALA Bulletin 42 (7): 285.

25. Florence Anderson, 1963, Carnegie Corporation: Library Program, 1911-1961 (New York, NY: Carnegie Corporation), 90. The small sum speaks volumes.

26. Mary B. McLellan, 1945, “There’s Still Work to Be Done with the Foreign Born,” Library Journal 70 (Aug. 1945): 676-77. 
Congressional deliberation and approval, Milam, ALA Executive Secretary, requested then CWFB chair Edna Phillips to conduct a study of the labor situation with Mexican migrants and to assess the needs for providing library services to them.

In June 1945, Phillips sent Milam a memorandum reporting that 75,000 Mexican migrant laborers were expected in July 1945 to work on farms in the West and Midwest. In addition to the need for seasonal agricultural workers, she noted that thirty-two railroads, covering the entire United States, had been assigned quotas of 100 to 12,750 Mexican laborers.

In her memorandum, Phillips referred to the work already in progress since 1939 with Mexican migrants in Ohio under the supervision of Edith Wirth of the Cleveland Public Library, a current member of the CWFB. Based on Wirth's initiative and its relative success, Phillips recommended the establishment of library service points in other migrant labor camps throughout the United States in her memorandum, which was distributed to library extension agencies. Back in 1939, the Cleveland Public Library had been the beneficiary of a grant of $\$ 5,000$ from the AAAE for extension of library service to labor and foreign language groups.

In the October 1946 minutes of the ALA CWFB, Phillips stated that her memorandum had generated interest in improving library services for the Mexican migrants working in the United States. The ending of World War II seemed to belie the need for further development of this the project. In the long run, the ALA missed an opportunity to develop a policy on providing library service to migrant laborers from Mexico and other parts of the Western Hemisphere, who were in the U.S. to provide much-needed farm and industrial labor. Congress eventually passed the Agricultural Act of 1949, which allowed for the use of migrant laborers from throughout the Western Hemisphere, especially from Mexico, to work as seasonal agricultural workers. As part of the 1949 act, the Mexican Bracero Program, which would last until 1964, was established in large part to satisfy the demands of farmers in the Midwest and Southwest. ${ }^{27}$

\section{Demise of the ALA CWFB}

From the end of World II onward, the ALA began to urge the CWFB to accept a new mission to improve international and intercultural relations. In October 1946, Phillips reported to the CWFB membership that negotiations were underway with ALA officials to bring about this change. Concurrently, during 1946, the Adult Education Section was established within the ALA Public Library Division. In October 1948, during the Atlantic City (NJ) ALA conference, the ALA Council approved that the name of the ALA CWFB be changed to the ALA Committee on Intercultural Action.

It remains an organizational mystery why the CWFB did not formally merge at that very moment with the ALA Adult Education Section, rather than becoming a new committee with a vague mission that detracted from the provision of Americanization services. Much enthusiasm and energy from many CWFB members and supporters of immigrants' rights were quashed as advocacy for multiculturalism seemed to take second place to the promotion of internationalism.
The new ALA Committee on Intercultural Action had four, seemingly unrelated, goals: (1) to foster tolerance and understanding among cultural groups; (2) to promote an appreciation for diversity among racial and ethnic groups; (3) to support the aims and work of the United Nations, especially UNESCO; and (4) to disseminate information on race, group $\mathrm{dy}$ namics, and techniques for handling potential violence due to racial friction. The only goal of the former CWFB that remained was promoting an appreciation for diversity, which broadly included multiculturalism.

Phillips served as chair of the newly formed committee whose principal reported activity was the provision of shipments of food or clothing to librarians in the countries serviced by CARE (Cooperative for Assistance and Relief Everywhere), founded in 1945. Although the Committee on Intercultural Action functioned at least organizationally through the 1956-57 fiscal year, its functions were then absorbed by the ALA Adult Services Section of the ALA Public Library Division. In retrospect, the Commission on Intercultural Action was of dubious value, proof of which lies in the absence of published minutes. ${ }^{28}$

\section{Carnegie Corporation and Adult Education}

In 1948, the third edition of Handbook of Adult Education in the United States, an article titled "Education of the Adult Foreign Born for Citizenship," by Henry B. Hazard of the U.S. Department of Justice, Immigration and Naturalization Service, was published along with an article titled "The Public Library and Adult Education," by Mildred V. D. Mathews, Supervisor of

27. ALA, 1945, "ALA CWFB Minutes," ALA Bulletin 39 (10): 401; ALA, 1947, "ALA CWFB Minutes," ALA Bulletin 41 (11): 401-2; ALA, 1948a, "ALA

CWFB Minutes," ALA Bulletin 42 (2): 69-70; ALA, 1948b, "ALA CWFB Minutes," ALA Bulletin 42 (11): 464; Lemay and Elliott, 220-225; Library

Program, 1911-1961, 88.

28. ALA, 1947; ALA, 1948a; ALA, 1948b; Chronology, 2002, 3. 
Adult Services of New York Public Library (NYPL). Together these articles demonstrated the continued involvement of both the federal government and the ALA in the education of the foreign born and especially in the preparation for naturalization leading to citizenship. ${ }^{29}$

\section{Ford Foundation's Fund for Adult Education}

When the Carnegie Corporation withdrew funding for the ALA adult education program in 1951, the Ford Foundation's subsidiary Fund for Adult Education (FAE), stepped in to fund the Adult Education Association of the United States (AEA) from 1951 to 1961. The Ford Foundation was founded in 1936 by Edsel and Henry Ford, conservative businessmen, who could hardly have been cast as advocates of immigrants' and workers' rights. By 1951 this antagonism had been tempered by its new commitment to funding adult education programs for preserving democracy.

In 1951, an initial FAE grant to the ALA consisted of $\$ 150,000$ for the implementation of the American Heritage Project, directed by Grace T. Stevenson, Executive Secretary of the ALA Adult Education Board. This project was carried out by public library discussion groups on American democracy. The project was based on the Great Books reading courses formulated in the late 1940 s by the Great Books Foundation in Chicago. This project was used by the NYPL to explore a program known as Exploring the American Idea (EAI). In the spring and summer of 1951, the EAI was transformed from a local program of the NYPL to a national program of the ALA.

The EAI attracted the attention of C. Scott Fletcher, head of the new Fund for Adult Education. Created by the Ford Foundation in its effort to settle its tax status with the IRS. Fletcher informed John Mackenzie Cory, Carl Milam's replacement as ALA Executive Director, of the FAE board's approval of a $\$ 150,000$ grant to ALA for the promotion and demonstration of adult community discussions on the American heritage and its contemporary application. ALA was to coordinate and support local program activities, select six demonstration areas, and conduct a training program. $^{30}$

\section{The American Heritage}

\section{Project was ALA's first} national adult education program to be centralized in both theme and

The grant promised, according to Jean Preer, "a greatly expanded audience for the public library as an independent agent of adult education." The American Heritage Project (AHP) was ALA's first national adult education program to be centralized in both theme and implementation. The AHP provided reading materials through its office along with training and consultation. The EAI and AHP seemed to fulfill the recommendations of the Public Library Inquiry (PLI), published by Columbia Press from 1949 to 1951. Finding that only a small fraction of the public used the public library and tended to seek popular, ephemeral material, the PLI challenged the notion of the library as a bulwark of democracy. The study concluded that libraries were limited by the self-selected nature of their audience and the emergence of mass media. Libraries should concentrate on reaching local community elites with serious works of long-lasting interest. The FAE had a strong interest in film and collaborated with Scott Fletcher, former head of Encyclopaedia Britannica Films, and Grace Stevenson, head of the AHP, a pioneer in the use of films at the Seattle Public Library. ${ }^{31}$

\section{Immigration and Nationality Act of 1952}

Amid the discussions and actions regarding the adult education role of the public library, important immigration was passed by the U. S. Congress. The immigration legislation of 1952 maintained the national-origins quota system initiated in the National Origins Act of 1924, however, it allowed limited immigration from the countries of the Asia Pacific Triangle, a new geographical construct first defined in the 1952 act. This immigration reform opened the possibility for Asian

29. Henry B. Hazard, 1948, "Education of the Adult Foreign Born for Citizenship," in Handbook of Adult Education in the United States, comp. under the auspices of the Institute of Adult Education, Teachers College, Columbia University, with the cooperation of the American Association for Adult Education, Mary L. Ely, ed. (New York, NY: Bureau of Publications, Teachers College, Columbia University); Mildred V. D. Mathews, 1948, “The Public Library and Adult Education," in Handbook of Adult Education in the United States, comp. under the auspices of the Institute of Adult Education, Teachers College, Columbia University, with the cooperation of the American Association for Adult Education, ed. by Mary L. Ely (New York, NY: Bureau of Publications, Teachers College, Columbia University).

30. Jean L. Preer, 2001, "Exploring the American Idea at the New York Public Library." American Studies 42:3 (Fall): 135-54, in The Library as an Agency of Culture. 2001. Ed. by Thomas Augst and Wayne A. Wiegand (Madison, WI: University of Wisconsin Press, 2001, 143-50, 144 (quote).

31. Grace T. Stevenson, 1954, "The ALA Adult Education Board," ALA Bulletin 48 (4): 226-31; Stevenson, 1960, "Adult Education in Libraries," in Handbook of Adult Education in the United States, Malcolm S. Knowles, ed. (Chicago, IL: Adult Education Association of the U.S.A.). 
immigration from countries formerly identified in the National Origins Act of 1924 as the Asiatic Barred Zone. ${ }^{32}$ Library services for Asian immigrants increased due to demands of immigration.

\section{ALA Office of Adult Education}

In 1952, there was good news on the funding front for libraries. Additional FAE funding was granted to the ALA to create an Office of Adult Education. FAE grant programs developed in the 1950 s were more concerned with materials being used in library study and discussion groups rather than on the audiences being served. Although some library leaders questioned the efficacy of group-oriented adult education, Stevenson of the ALA Adult Education Board disagreed. She argued that adult education group discussions encouraged their participants to use library materials more effectively. Stevenson's view prevailed. Between 1951 and 1955, the FAE funded twenty ALA Adult Education Subgrant Projects, which provided funding for small group discussion programs in public libraries. ${ }^{33}$

The ALA Survey of Adult Education Activities, funded by a FAE grant, was conducted in 1952 and 1953 by Helen Lyman Smith, and published in 1954 as Adult Education Activities in Public Libraries. Her report, which dealt extensively with group library services for adults, demonstrated the differences in opinion among librarians and library adult education specialists. Librarians in general gave priority to publicity, including exhibits, lectures, and book talks. Library adult education specialists gave priority to community leadership program planning, counseling on library resources, the use of library materials in librarysponsored programs, and library staff training.

The Smith survey documented that of the 1,692 public libraries responding, only 364 conducted studies of community needs and resources. Of the remaining 1,328 which did no community studies to determine local needs, only 146 expressed any interest. Of the libraries surveyed, only 9 percent offered adult library services with the foreign born, the term used in the report. ${ }^{34}$

\section{ALA Library- Community Project}

In 1955, renewed interest in library adult education was promoted by a FAE grant to the ALA Library-Community Project, which continued until 1960 under the direction of Ruth Warncke. The Library-Community Project was implemented to follow up on the distressing finding in the Smith survey that many libraries had no interest in surveying their communities to determine what adult services were needed. It was assumed that, if these uninterested libraries were given help from qualified adult education consultants, they would respond more positively. This FAE grant provided funds for consultants to help pilot libraries undertake community surveys of their users. In 1957, the ALA Adult Education Section became the ALA Adult Services Division (ASD), which incorporated the ALA Adult Education Board, established earlier in $1926 .{ }^{35}$

\section{Beginning of Federal Funding for Libraries}

In 1956, federal funding for libraries became a reality, after years of lobbying the U.S. Congress by the ALA. The Library Services Act (LSA) (195664) helped many libraries, particularly in the South, to develop and implement services with African Americans, a long-neglected minority population. The Library Service \& Construction Act (LSCA and its amendments) (1964-95) provided funds for library programs to reach immigrants from around the world, particularly Asia, which had been sorely neglected due to former U.S. immigration policies and legislation.

Finally, the Library Services \& Technology Act (LSTA) (1996- ) granted funds to serve two more neglected minorities, American Indians and Native Hawaiians. Federal aid to libraries has become part and parcel of government support for public libraries, but always with the requirement of Congressional oversight and the need for reauthorization of the enabling laws. ${ }^{36}$

32. M.A. Jones, American Immigration, 251-55; Mary Elizabeth Brown, "Patrick Anthony McCarran (1876-1954): Cold War Immigration," in Shapers of the Great Debate on Immigration: A Biographical Dictionary (Westport, CT: Greenwood Press, 1999), 191-204; LeMay and Barkan, U.S. Immigration and Naturalization Laws and Issues, 116-21.

33. Eleanor Phinney, ALA Projects: Supported by the Fund for Adult Education," ALA Bulletin 50 (9) (1956): 591-96.

34. Helen Lyman Smith, 1954, Adult Education Activities in Public Libraries; A Report of the ALA Survey of Adult Education Activities in Public Libraries and State Library Extension Agencies of the United States (Chicago, IL: ALA), 17, 21, 37; Monroe, 1963, 61-62; Chronology, 2002, 3).

35. Ruth Warncke, 1960, Library-Community Project Report, 1955-1960 (Chicago, IL: ALA, prepared for the Fund for Adult Education); Monroe, 1963, 65-66; Chronology, 2002, 3. One such pilot project was with the Cumberland County Public Library which had reported a large collection of foreign language materials and requested consultants to demonstrate how these materials could be used in Cumberland County, the home of Fort Bragg, and throughout North Carolina The North Carolina Foreign Language Center, with Library Services and Construction Act funds, was founded in 1976 and included an initial donation of 2,000 foreign-language books from the Cumberland County (NC) Library, with its headquarters in Fayetteville.

36. Stevenson, 1960; Angelica W. Cass, 1960, "Fundamental and Literacy Education for Natives and Foreign-Born Adults, in Handbook of Adult Education in the United States, Malcolm S. Knowles, Ed. (Chicago, IL: Adult Education Association of the U.S.A.). 
The 1960 edition of the Handbook of Adult Education in the United States, published with a FAE grant of $\$ 10,484$ included two articles touching upon library work with immigrants. Grace Stevenson of the ALA reviewed the state of the art in adult education programs sponsored by public libraries throughout the United States. Angelica W. Cass, Associate in Americanization and Adult Elementary Education of the New York State Education Department, in her article, "Fundamental and Literacy Education for Natives and Foreign-Born Adults," demonstrated the continued cooperation between public schools and the federal government through the Immigration and Naturalization Service of the U.S. Department of Justice, and the U.S. Office of Education. ${ }^{37}$

Cass's article spoke to the fact that Americanization services were nationally important and not dependent on the ALA alone. The reality was that Americanization services, no matter what they were called, were still needed and that the federal government and public and evening schools were prepared to take up any perceived gaps left by the ALA.

\section{FAE dissolved}

In 1961, after the FAE dissolved, further funding would come directly from the Ford Foundation. The FAE as its last granting round gave what was literally called final grants to the many national organizations, including the ALA, which received a grant of $\$ 40,000$ for funding local libraries in the development of demonstration programs in what the FAE referred to as liberal adult education. ${ }^{38}$

\section{Immigration Act of 1965}

In 1965, Congressional reforms of immigration were enacted to replace the existing national origins-based legislation, begun in 1924 and modified slightly in 1952, with a system based on preferences for certain categories of immigrants, particularly those who qualified for admission in order to reunite with family members already in the United States and those with occupational skills needed in the U.S. economy.

In order to accommodate the demands from factions demanding tougher security on the border, the exemptions, formerly allowed for immigrants from within the Western Hemisphere, were abandoned. A fateful consequence of this legislation was that the seasonal agricultural laborers who had worked in the United States since 1949, when the Mexican Bracero Program was established, were no longer permitted to resume their employment when the program ended in 1964. These workers, who returned to U.S. farms in the spring of 1965 to take up their former occupations, were viewed under the U.S. immigration law as undocumented or illegal laborers. ${ }^{39}$

The qualifying term "illegal" stuck though these immigrants had worked in the U.S. legally without the need for documentation up until 1965. From 1965 onward, Mexican migrant laborers were no longer viewed as helping the U.S. economy, as they had been during World War II when they provided needed services, but as a drain on U.S. resources to which they were not entitled.

\section{Adult Education Act (1966) \& American Association of School Librarians (1967)}

In 1966, Congress passed the Adult Education Act, giving adult education the status of being governmentally endorsed and funded. In response to the legislation, the American Association of School Librarians (AASL) in 1967 organized an Ad Hoc Committee on Treatment of Minorities in Library Materials to advocate for a more positive portrayal of immigrants in textbooks used by school children across the United States. David Cohen served as coordinator of this AASL committee from 1967 through 1972.

Concurrently, in 1970, the "Library Rights of Adults: A Call for Action" was adopted and endorsed by the Adult Services Division (ASD) and Reference Services Division (RSD). In 1972, the ASD and the RSD merged to become the ALA Reference \& Adult Services Division (RASD). In 1976, the Public Library Association (PLA) established an Alternative Education Programs Section (AEPS) to promote public library adult literacy programs, as well as adult basic education (ABE) and other continuing education programs. ${ }^{40}$

\section{National Survey of Library Services to non-English Language Speaking Minorities}

In the fall of 1980, Library Trends published a survey of library services to non-English-language ethnic minorities in the United States taken by Natalia B. Bezugloff, Head of the Foreign Literature Department of the Cleveland Public Library. She contacted 127 public libraries offering

\footnotetext{
37. Hansen, Andrew, 1985. "RASD: A Backward Look into the Future," RQ 25 (1): 13-18; Hansen, 1995. "RASD: Serving Those Who Serve the Public," RQ34 (3): 314-38; Hansen, 2013, RASD: Serving Those Who Serve the Public, accessed Nov. 15, 2013, two-part document, http://www.ala.org/rusa/about/ history; and http://www.ala.org/rusa/about/history/rasdhistory2.

38. A Ten Year Report of the Fund for Adult Education, 1951-1961 [New York, NY: Ford Foundation, 1962].

39. Francesco Cordasco, "Bracero Program," in Dictionary of American Immigration History (Metuchen, NJ: Scarecrow Press, 1990$), 91$.

40. Chronology of Milestones for Libraries and Adult Lifelong Learning and Literacy, 2002, prepared for the ALA Committee on Literacy, by Kathleen de la Pena McCook and Peggy Barber, 2-4 (Washington, DC: ERIC).
} 
multilingual library services in 50 states. Of the 102 responses she received, 72 had foreign-language collections of various sizes in more than 70 foreign languages.

Of the 45 libraries that reported the age of their collections, 10 were started before 1900, 13 in the early 1900 s before World War I, and 22 since World War I. These 45 libraries provided a variety of services to the ethnic communities they served, including readers' advisory service, and visits to and materials for English as a Second Language (ESL) and citizenship classes. The most positive outcome reported was a marked increase in use of foreignlanguage and language-learning materials by second- and third-generation descendants of immigrants. ${ }^{41}$ Bezugloff's research demonstrated the continuing need for multicultural adult library services.

\section{Establishment of ALA Ethnic Materials Information Ex- change Round Table}

In the summer of 1982, the Ethnic Materials Information Exchange Task Force (EMIE) of the Social Responsibilities Round Table (SRRT) was elevated to the administrative status of $s$ round table at the ALA annual conference in Philadelphia. The decision was viewed by many EMIERT members as tangible recognition of the continued importance of advocacy for multiculturalism within the ALA. The upgrading also gave EMIERT the gravitas to collaborate with other agencies interested in library service with ethnic and minority groups. The petition, presented by David Cohen, formerly with the AASL and the EMIE task force in the SRRT, was approved and supported by the ALA Council Committee on Minority Concerns. ${ }^{42}$

\section{Immigration Reform and Control Act of 1986}

Immigration legislation in 1986 attempted to stem the tide of illegal immigration, which had continued to rise since 1965 , by instituting employer sanctions for those employers who knowingly hired undocumented alien workers. An amnesty program was update of Helen Lyman Smith's 1954 survey which had been sponsored by the FAE. ${ }^{44}$

An analysis of the survey, edited by Kathleen M. Heim and Danny P. Wallace, was published by the ALA in 1990 as Adult Services: An Enduring Focus for Public Libraries. The results of the survey documented increases in and improvements to services with immigrants and minorities since the Smith survey. The questionnaire was distributed to 1,758 library systems, also implemented to provide permanent resident-alien status to an estimated three million illegals already residing in the U.S. since January 1, 1972, including one and one-half million undocumented aliens and over one million special agricultural workers already in the country. Both the employee sanctions and the amnesty program were equally ineffectual: undocumented immigration continued. ${ }^{43}$

In 1989, the ALA Literacy Assembly was convened for the first time, and the former PLA Alternative Education Program Section was renamed the Adult Lifelong Learning Section. In 1990, the ALA RASD Services to Adults Committee announced the completion of a survey of adult education programs in public libraries. The survey, begun earlier in 1983 as the Adult Services in the Eighties (ASE) project, represented an expansive representing more than 8,000 singleunit libraries, central libraries, and branches. Responses were received from 4,215 individual libraries representing 1,114 systems. Results showed that public libraries had organized 18 programs based on the needs of ethnic and minority groups, including multicultural understanding, business operations, tax help, genealogical research, and political issues. States that offered 10 or more programs either for specific minorities or based on minority concerns included California, with 66; New York and Illinois, with 27 each; Texas, with 26; and Massachusetts, with 11 . Only 504 libraries out of the 4,215 responding, a little less than 12 percent, reported programming aimed at advocacy for multiculturalism and the human rights of minority clienteles. ${ }^{45}$

41. Natalia B. Bezugloff, "Library Services to Non-English-Language Ethnic Minorities in the United States," Library Trends 29 (Fall 1980): $259-74$.

42. J. B. Petty, 2001, "Reflections on the Role of EMIERT in the Past and in the Future: A Message from the Chair," EMIE Bulletin 18 (3): 1 , 3 , 13.

43. LeMay \& Barkan, xlv, 282-288; P. A. Jones, Jr., Still Struggling for Equality: American Public Library Services with Minorities (Westport, CT: Libraries

Unlimited, 2004), 123-24; Cordasco, "Immigration Reform and Control Act of 1986" in Dictionary of American Immigration History, $391-96$.

44. William E. Moen and Kathleen M. Heim, eds., Librarians for the New Millennium (Chicago, IL: ALA, Office for Library Personnel Resources, 1988).

45. Kathleen M. Heim, \& Danny P. Wallace, 1990, Adult Services: An Enduring Focus for Public Libraries (Chicago: ALA); Heim, 1991, "Adult Services within the American Library Association: A Historical Examination of the Move to Synthesis." RQ 30 (3): 386-94. 


\section{Immigration Act of 1990}

Immigration legislation in 1990 established a new category of preference called "diversity immigrants," who came to the United States from traditional sources of immigration such as Ireland, Italy, and Poland. The category of diversity immigrants included an interesting combination of what had once been in the 1920s referred to as "old immigrants" (from Ireland, for example) and what were referred to as "new immigrants" (from Italy and Poland, for example). ${ }^{46}$

In 1991, the creation of the $\mathrm{Na}-$ tional Institute for Literacy (NIFL) was enabled by a bipartisan Congressional coalition in response to requests for a national literacy agency. In 1995, the former ALA Office for Library Outreach Services (OLOS) retained its acronym, however, it was renamed the ALA Office for Literacy and Outreach Services (OLOS) to recognize its expanded focus on adult literacy and advocacy for multiculturalism. ${ }^{47}$

\section{Adult Education and Family Literacy Act of 1998}

In 1998, the ALA adopted literacy as one of five key action areas. The Adult Education Act (AEA) of 1966 was restructured as the new Adult Education and Family Literacy Act (AEFLA) to emphasize the continuing need for adult literacy activities and the fact that adult literacy reinforced by adults reading with their children. In 2001, the ALA Standing Committee on Literacy was established. ${ }^{48}$

\section{Department of Homeland Security established after 9/11/2001}

The tragedy of 9/11/2001 dramatically changed the debate on immigration reform to one on defeating global terrorism. In 2002, the new Department of Homeland Security was established to deal with immigration, terrorism, response to natural disasters, and a host of other responsibilities formerly administered by several federal agencies. In 2007, amid wars in Iraq and Afghanistan, the U.S. Senate passed a Comprehensive Reform of Immigration bill, which had the potential of fixing the immigration process, particularly about the issue of illegal immigration, but it languished and died without approval from the U.S. House. ${ }^{49}$

\section{Beginning of the Deferred Action for Childhood Arrivals (DACA) (2012)}

During the Obama administration, on June 15, 2012, then-Secretary of Homeland Security Janet Napolitano issued a memorandum entitled "Exercising Prosecutorial Discretion with Respect to Individuals Who Came to the United States as Children." This memorandum created a non-Congressionally-authorized administrative program that permitted certain individuals who came to the United States as juveniles to request consideration of deferred action for a period of two years, subject to renewal, and eligibility for work authorization. The program became known as Deferred Action for Childhood Arrivals (DACA). It must not be forgotten that DACA status does not equate to legal status, while the DREAM act would..$^{50}$

\section{Immigration in the Trump Era}

In 2014, the need for comprehensive immigration, which was passed in the Senate but not by the House earlier in 2007, was once again brought to debate in the U.S. Congress due to the massive immigration of children, some with their mothers, to flee brutal regimes, gangs, and drug cartels in the Central American nations of Honduras, Guatemala, and El Salvador. ${ }^{51}$

In November 2016, President Trump banned travel to the United States by refugees and immigrants from some majority-Muslim countries and ordered that sanctuary cities refusing to cooperate with the federal government to facilitate deportations would lose their federal funding. He directed the Department of Homeland Security to build a wall on the U.S.Mexico border, hire 5,000 new Border Patrol agents and construct new detention facilities. In August 2017, Trump wasted no time setting a deadline for the expiration of DACA. He challenged Congress to come up with a solution for the already registered Dreamers.

On September 5, 2017, then-U.S. Attorney General Jeff Sessions announced that the government was terminating the DACA program. That same day, then-Acting Secretary of

46. M. A. Jones, American Immigration, 289-90; E. Willard Miller and Ruby M. Miller, United States Immigration: A Reference Handbook (Santa Barbara, C

A: ABC-CLIO, 1996), 103-7; Thomas J. Archdeacon, "Immigration Law," in Oxford Companion to United States History, 366.

47. Chronology of Milestones, 2-4.

48. Ibid.

49. Plummer Alston Jones, Jr., "From Marginalized Migrants to Permanent Residents of North Carolina: How Libraries and Latinos Are Collaborating to Build Multicultural Communities in the Tar Heel State," North Carolina Libraries 77 (1) (Spring/Summer 2019): 5; Hannah Gill, 2018, The Latino Migration Experience in North Carolina: New Roots in the Old North State. 2nd ed., rev. and exp. (Chapel Hill, NC: University of North Carolina Press, 2018), 166-170.

50. Chronology, 2-4.

51. U.S. Department of Homeland Security, 2020, Secretary Napolitano Announces Deferred Action Process for Young People Who Are Low Enforcement Priorities, 1 of 3, available from https://www.dhs.gov/news/2012/06/15-secretary-napolitano-annou 
Homeland Security Elaine Duke issued a directive to the U.S. Department of Homeland Security to reject all initial DACA applications and associated applications for work authorization received after September 5, 2017. In the days and months following, multiple lawsuits challenging the Trump administration's actions to terminate DACA were filed across the country. Two U.S. district courts halted the government's termination of DACA and required the U.S. Citizenship and Immigration Services (USCIS) to continue accepting renewal DACA applications from individuals who had previously had DACA. In reaction to the U.S. Attorney General's call for the termination of the DACA program, North Carolina's Attorney General Josh Stein joined fifteen other states in a lawsuit challenging Trump's plans to cancel the DACA program and declared that even without formal immigration status, DACA recipients were to be granted legal presence in North Carolina. ${ }^{52}$

\section{DACA's future remains uncertain}

On January 22, 2018, the Supreme Court of the United States (SCOTUS) decided not to take the DACA case during the 2017-18 term, but that DACA renewals would remain open for people eligible to renew. DACA recipients were encouraged to continue renewing their status as the SCOTUS would hopefully take the case on in the next available termwhich would begin on October 1, 2019.53

On May 1, 2018, Texas and six other states filed a lawsuit in the U.S. District Court for the Southern District of Texas challenging the 2012
DACA program itself. On May 2, the plaintiffs asked the court to issue a preliminary injunction that would stop USCIS from adjudicating applications for deferred action under DACA while the lawsuit was pending. After an August 8, 2018 hearing in Houston, Texas, on whether to grant a preliminary injunction, the court denied the plaintiff states' request, concluding that such an injunction would not be in the public's interest. As a result of this decision, individuals who had or previously had DACA status could apply to renew it.

The 2018 midterm elections saw the Democrats win a majority in the House, but not in the Senate. Negotiations on the DREAM Act and DACA continued to be blocked by the Republican majority in the Senate. On June 28, 2019, the SCOTUS announced that it would hear the case on DACA to determine the program's future. It was hoped that a decision in the case would come sometime between January and June 2020.

As of February 2020, the immigration situation became even more brutal. The DACA program remained in effect and recipients continued to renew their status, although those immigrants who had never had DACA status still could not apply. Reform is needed to block the Trump administration's efforts to deny political asylum to Latinx immigrants.

At long last, after months of waiting for SCOTUS to act, DACA was upheld on Thursday, June 18, 2020, with a band of proud Dreamers carrying a banner on the steps of the U.S. Supreme Court that read "Home Is Here." 54 President Obama's executive order remained in effect while Dreamers awaited the approval of an immigration reform act to be passed by both the U.S. House of Representatives and the U.S. Senate.

As advocates of multiculturalism and immigrants' rights, public libraries throughout the country have voiced their opposition to President Trump's policies regarding immigrants and minorities. Throughout the country, particularly in so-called Sanctuary Cities, many DACA recipients as well as other undocumented immigrants live and contribute to the state and national economies. Public libraries continue to provide programs and resources to help immigrants and minorities to make their livelihoods and homes in the United States and to help them to become full citizens.

Library advocacy for multiculturalism has reached a tipping point. Without stronger support in terms of continued funding from local, state, and federal funding sources, advocacy for immigrants and minorities cannot be sustained. As the novel coronavirus ravages the country and the world, the focus of Congressional efforts and state legislatures is undeniably on saving lives, but it is equally important to maintain a quality of life that libraries have provided since 1876 . Congressional support in terms of funds for increasing computer access and band width throughout the country is necessary to keep Americans informed daily about how to combat the virus and other survival tips.

Many libraries are prepared to help with this challenge and many others would be if funding were provided directly to them. Advocacy for immigrant and minority rights depends now more than ever on Congressional reform of a broken immigration system.

52. Gill, Latino Migration Experience in North Carolina, 172-73, 175-79.

53. National Immigration Law Center (NILC), 2020, Status of Current DACA Litigation, 1-6 of 15, available from https://www.nilc.org/issues/daca/statuscurrent-daca-litigation/; Immigrants Rising: DACA Updates, 2020, 1-3, available from https://immigrantsrising.org/daca-updates/.

54. Ibid.; MSNBC nightly news programs on June 18, 2020 promulgated the good news for Dreamers and their supporters. 